Jurnal Penelitian Farmasi Indonesia 9(1), Juni 2020

ISSN : 2302-187X $\quad e$-ISSN 2656-3614

\title{
UJI EFEK ANALGETIK INFUSA DAUN JERUK NIPIS (Citrus aurantifolia (Christm.) Swing) TERHADAP MENCIT PUTIH (Mus musculus L) JANTAN YANG DIINDUKSI ASAM ASETAT 1\%
}

\author{
Novia Sinata ${ }^{1}$, Akmal Luthfi ${ }^{2}$

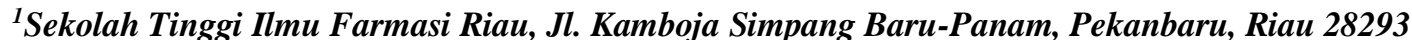 \\ Telp. 0761-588006 \\ e-mail: ${ }^{1 *}$ noviasinatafarmasi@gmail.com , 2*15akmal-luthfi@stifar-riau.ac.id
}

\begin{abstract}
ABSTRAK
Telah dilakukan penelitian uji efek analgetik infusa daun jeruk nipis (Citrus aurantifolia (Christm.) Swing) terhadap mencit putih (Mus musculus $\mathrm{L}$ ) jantan diinduksi asam asetat $1 \%$. Tujuan penelitian ini adalah untuk melihat pengaruh efek analgetik infusa daun jeruk nipis (Citrus aurantifolia (Christm.) Swing) terhadap mencit putih (Mus musculus L) jantan dengan menggunakan metoda Writhing Test. Hewan percobaan dibagi menjadi 5 kelompok. Kelompok kontrol negatif diberikan aquades, kelompok kontrol positif diberi asam asetil salisilat dengan dosis $1,3 \mathrm{mg} / 20 \mathrm{~g}$ BB yang disuspensikan dengan $\mathrm{Na}$ CMC $1 \%$, kelompok perlakuan diberi sediaan infusa daun jeruk nipis (Citrus aurantifolia (Christm.) Swing) dengan konsentrasi 5\%, 10\%, dan 20\%. Hewan percobaan tersebut diberikan sediaan peroral seban yak $1 \%$ BB, 30 menit setelah diinduksi dengan asam asetat $1 \%$ sebanyak $0,1 \mathrm{ml}$ secara ip. Hasil uji Anova Dua Arah menunjukan bahwa infusa daun jeruk nipis pada konsentrasi 10\% dan 20\% (Citrus aurantifolia (Christm.) Swing) mampu mengurangi rasa nyeri pada mencit yang diinduksi asam asetat glasial $1 \%$, berbeda signifikan dengan kelompok kontrol negatif $(\mathrm{p}<0.05)$ namun efeknya belum sekuat asam asetil salisilat (kontrol positif).
\end{abstract}

Kata Kunci :Analgetik, infusa, daun jeruk nipis, asam asetat

\begin{abstract}
Research has been carried out on the analgesic effect of infusion of lime leaves (Citrus aurantifolia (Christm.) Swing) on male white mice (Mus musculus L) induced 1\% acetic acid.The purpose of this study was to see the effect of analgesic effect of infusion of lime leaves (Citrus aurantifolia (Christm.) Swing) on male white mice (Mus musculus L) using the Writhing Test method. Experimental animals were divided into 5 groups. The negative control group was only given aquades, a positive control group of acetyl salicylate acid with a dose of $1.3 \mathrm{mg} / 20 \mathrm{~g} \mathrm{BB}$ which was suspended with $1 \% \mathrm{Na}$ CMC, the treatment group was given a lime leaf infusion (Citrus aurantifolia (Christm.) Swing) with a concentration of $5 \%, 10 \%$ and $20 \%$.The experimental animals were given oral preparations as much as $1 \%$ BB, 30 minutes after which each group was induced with $1 \%$ acetic acid as much as $0.1 \mathrm{ml}$ ip. The data obtained is processed using two-way Analysis of Variance (ANOVA). The results showed that the infusion of lime leaves at concentrations of 10\% and 20\% (Citrus aurantifolia (Christm.) Swing) has analgesic effects on mice induced $1 \%$ acetic acid, .significantly different from negative controls ( $\mathrm{p}<0.05)$ but not as strong as acetyl salicylate (positive control)
\end{abstract}

Keywords : Analgetic, infusion, lime leaves, acetic acid 


\section{PENDAHULUAN}

Nyeri adalah perasaan sensoris dan emosional yang menggangu, berhubungan dengan ancaman, timbulnya gangguan atau kerusakan jaringan.Keadaan psikologis seseorang sangat berpengaruh, misalnya emosi dapat menimbulkan nyeri/sakit kepala atau membuatnya semakin parah.Ambang batas nyeri yang dapat ditoleransi seseorang berbeda-beda karena nyeri merupakan suatu perasaan subyektif (Sherwood, 2012).

Salah satu bahan alam yang dapat dimanfaatkan sebagai pengobatan tradisional adalah daun jeruk nipis (Citrus aurantifolia (Christm.) Swing). Daun jeruk nipis mengandung senyawa flavonoid, selain flavonoid bagian daun juga mempunyai kandungan seperti: sitrat, limonene, lemon kamfer, fellandrena, geranil asetat, kadinena, linalin asetat, asam sitrat 7-7,6\%, damar, mineral, vitamin B1 dan C. Flavonoid berperan sebagai analgetik yang mekanisme kerjanya menghambat kerja enzim siklooksigenase dengan mengurangi produksi prostaglandin oleh asam arakidonat sehingga dapat mengurangi rasa nyeri (Gunawan, 2008, Anna, 2012).

Berdasarkan penelitian yang dilakukan oleh eka prasasti clearinsyah (2016) menggunakan ekstrak daun jeruk nipis sebagai analgetik yang diberikan kepada mencit yang telah diinduksi asam asetat $1 \%$ menggunakan metode writhing reflex mendapatkan hasil penurunan jumlah writhing reflex dengan persentase proteksi untuk kontrol positif $(91,96 \%)$, dosis ekstrak 1,3 $\mathrm{mg} / 20 \mathrm{gBB}(80,63 \%)$, dosis ekstrak 2,6 mg/20gBB $(88,63 \%)$ dan dosis ekstrak $5,2 \mathrm{mg} / 20 \mathrm{gBB}$ $(96,46 \%)$.Oleh karena itu, tujuan penelitian ini untuk mengetahui pengaruh efek analgetik pemberian infusa konsentrasi infusa yang digunakan yaitu $5 \%, 10 \%$, dan $20 \%$ daun jeruk nipis terhadap mencit putih (Mus musculus L) jantan yang di induksi asam asetat $1 \%$ dengan mengamati jumlah geliatan hewan uji.

\section{METODE PENELITIAN}

\subsection{Alat Penelitian}

Alat yang digunakan terdiri dari Panci infusa, kain flanel, batang pengaduk, neraca analitik, neraca hewan, stopwatch, pipet tetes, gelas ukur, beker gelas, tempat minum mencit, kandang mencit, lumpang, stamfer, sonde oral, jarum suntik.

\subsection{Bahan Penelitian}

Bahan yang digunakan dalam penelitian ini adalah daun jeruk nipis, asam asetat $1 \%$, Aquadest, Tablet Asam asetil salisilat (Asetosal),
Na CMC 1\%, Norit, Asam sulfat pekat, Asam asetat anhidrat, HCL pekat, $\mathrm{FeCl}$, Logam magnesium, Pereaksi Mayer, Pereaksi Dragendorf.

\subsection{Prosedur Penelitian}

\subsubsection{Pengambilan Sampel Daun Jeruk Nipis}

Daun jeruk nipis yang digunakan untuk pembuatan infusa dalam pengujian efek analgesik adalah daun jeruk nipis yang masih segar dan baik, diambil dari Desa Salo, Kecamatan Salo, Kabupaten Kampar, Riau

\subsubsection{Skrining Fitokimia}

Analisis fitokimia merupakan analisis kualitatif yang dilakukan untuk mengetahui komponen bioaktif yang terkandung dalam tiap sampel. Analisis fitokimia yang dilakukan meliputi uji alkaloid flavonoid, fenolik, saponin, terpenoid dan steroid.

\section{Uji Alkaloid}

Daun jeruk nipis digerus dalam lumpang kemudian ditambahkan $5 \mathrm{ml}$ kloroform dan $5 \mathrm{ml}$ kloroform amoniak $0,05 \mathrm{~N}$, digerus secara perlahan, lalu saring larutan tersebut dengan meletakan kapas di dalam lumpang, kemudian masukan hasil saringan tersebut ke dalam tabung reaksi, sedangkan untuk infusa daun jeruk nipis diambil $1 \mathrm{ml}$. Tambahkan 10 tetes asam sulfat $2 \mathrm{~N}$ kocok hingga 1 menit, biarkan sampai terjadi pemisahan. Setelah itu lapisan atas (asam) kemudian pindahkan ke dalam tabung reaksi lain dan tambahkan beberapa tetes pereaksi Mayer. Reaksi positif ditandai dengan adanya kabut putih hingga gumpalan putih atau endapan.

\section{Pemeriksaan Flavonoid, Fenolik, Terpenoid, Steroid dan Saponin \\ Daun jeruk nipis digerus di dalam lumpang} kemudian masukan ke dalam tabung reaksi dan dimaserasi dengan etanol lalu panaskan selama 15 menit hingga pelarut etanol menguap dan mengering, sedangkan untuk infusa diambil sebanyak $1 \mathrm{ml}$ lalu ditambahkan $5 \mathrm{ml}$ aquadest dan kloroform di dalam tabung reaksi. kemudian kocok lalu dibiarkan beberapa saat sampai terbentuk 2 lapisan. Lapisan air digunakan untuk pengujian flavonoid, fenolik dan saponin. Lapisan kloroform digunakan untuk uji terpenoid dan steroid.

a. Uji Flavonoid

Beberapa tetes lapisan air dimasukan ke dalam plat tetes, kemudian masukan 2 buah logam $\mathrm{Mg}$ dan 2 tetes asam klorida pekat, begitu juga untuk skrining infusa daun jeruk nipis. Hasilnya 
menunjukan terbentuknya warna jingga sampai merah berarti adanya flavonoid.

b. Uji Fenolik

Beberapa tetes lapisan air dipindahkan ke plat tetes dan ditambahkan beberapa tetes larutan besi (III) klorida, begitu juga untuk skrining infusa daun jeruk nipis. Reaksinya ditandai dengan adanya warna biru gelap.

\section{c. Uji Saponin}

Ambil beberapa ml lapisan air kemudian masukan ke dalam tabung reaksi lalu kocok, begitu juga untuk skrining infusa daun jeruk nipis, jika terbentuk busa yang tetap selama 5 menit menandakan posistif adanya saponin.

d. Uji Terpenoid dan Steroid

Lapisan kloroform disaring dengan norit yang diletakkan ke dalam pipet tetes yang diberi kapas di ujungnya, begitu juga untuk lapisan kloroform yang diambil dari infusa, kemudian ditampung pada tiga lubang plat tetes tersebut, setelah kering pada lubang pertama tambahkan asam anhidrat, lubang kedua ditambahkan asam sulfat pekat sama banyak dan lubang ketiga asam asetat anhidrat dan asam sulfat pekat sama banyak, jika terbentuk warna merah pada salah satu lubang tersebut maka menunjukan adanya senyawa terpenoid dan warna biru ungu menunjukan adanya senyawa steroid.

\subsubsection{Persiapan Hewan Percobaan}

Hewan percobaan yang digunakan pada penelitian ini adalah mencit putih (Mus musculus L) jantan dewasa yang sehat sebanyak 25 ekor.Umur mencit yang digunakan berkisar antara 2-3 bulan dengan berat antara 20-30 gram.Sebelum perlakuan hewan percobaan di aklimatisasi selama 7 hari. Hewan yang digunakan untuk penelitian adalah hewan yang belum pernah diperlakukan terhadap obat dan hewan yang dinyatakan sehat dengan kriteria tidak cacat secara fisik, tidak mengalami penyimpangan berat badan $\pm 20 \%$ dan secara visual memperlihatkan perilaku yang normal (Anonim, 2014).

\subsubsection{Perencaan Dosis}

Konsentrasi infusa daun jeruk nipis yang diberikan pada hewan percobaan sebagai perlakuan pada mencit yaitu dengan 3 perlakuan konsentrasi 5\%, 10\%, 20\% dengan volume pemberian $1 \% \mathrm{BB}$. Untuk kelompok kontrol positif diberi asetosal untuk mencit 20 gram jika dikonversikan $=0,0026$ × $500 \mathrm{mg}=1,3 \mathrm{mg} / 20 \mathrm{~g}$ BB. Setelah itu larutkan dengan aquadest dan suntikan secara oral sebanyak $1 \%$ BB untuk masing-masing mencit. Sementara untuk kelompok kontrol negatif hanya diberikan aquadest sebanyak $1 \mathrm{ml}$.

\subsubsection{Pembuatan Infusa Daun Jeruk Nipis (Citrus aurantifolia (Christm.) Swing)}

Infusa dibuat dari daun jeruk nipis $10 \% \mathrm{~b} / \mathrm{v}$ dengan cara sebagai berikut, daun jeruk nipis seberat 10 gram kemudian dimasukan ke dalam panci infusa, ditambahkan aquadest $100 \mathrm{ml}$. Daun jeruk nipis yang telah ditambahkan aquadest dipanaskan menggunakan kompor selama 15 menit terhitung setelah suhu dalam panci mencapai $90^{\circ} \mathrm{C}$, sambil sesekali diaduk. Diserkai selagi panas dengan menggunakan kain flannel, dijadikan $100 \mathrm{ml}$ infusa.Jika volumenya kurang dari $100 \mathrm{ml}$ dapat ditambahkan air panas yang dilewatkan pada ampas daun jeruk nipis sehingga diperoleh $100 \mathrm{ml}$ volume infusa daun jeruk nipis. Infusa daun jeruk nipis yang diberikan sebagai perlakuan pada mencit yaitu dengan 3 perlakuan konsentrasi 5\%, 10\%, 20\% dengan volume pemberian $1 \% \mathrm{BB}$.

\subsubsection{Pembuatan Sediaan Uji Asam Asetil Salisilat}

Pembuatan suspensi asam asetil salisilat dosis $1,3 \mathrm{mg} / 20 \mathrm{gBB}$. Sampel asetosal dibuat dengan dosis $65 \mathrm{mg} / \mathrm{kgBB}$, pembuatannya dengan menaburkan 0,10 gram $\mathrm{Na}$ CMC ke dalam lumpang yang berisi air panas, dimana air panas yang digunakan 20 kali berat dari $\mathrm{Na}$ CMC. Didiamkan selama 15 menit hingga diperoleh $\mathrm{Na}$ CMC dengan masa yang mengambang dan transparan, digerus hingga berbentuk suspensi, taburkan asetosal yang telah ditimbang lalu digerus hingga homogen kemudian diencerkan dengan aquades hingga $10 \mathrm{ml}$.

\subsubsection{Pembuatan dan Penginduksian Asam Asetat Glasial $1 \%$}

Pembuatan asam asetat 1\% dengan cara pengenceran menggunakan asam asetat glasial 100\% dengan menggunakan rumus :

$\mathrm{V} 1 \times \mathrm{C} 1=\mathrm{V} 2 \times \mathrm{C} 2$.

$\mathrm{V} 1 \times \mathrm{C} 1=\mathrm{V} 2 \times \mathrm{C} 2$

$\mathrm{V} 1 \times 100 \%=10 \mathrm{ml} \times 1 \%$

$\mathrm{V} 1 \times 100 \%=10 \mathrm{ml}$

$\mathrm{V} 1=10 \mathrm{ml} / 100 \%$

$\mathrm{V} 1=0,1 \mathrm{ml}$

Keterangan :

$\mathrm{V} 1=$ Volume asam asetat glasial $100 \%$ 
$\mathrm{V} 2=$ Volume asam asetat glasial $1 \%$

$\mathrm{C} 1=$ Konsentrasi asam asetat glasial $100 \%$

$\mathrm{C} 2=$ Konsentrasi asam asetat glasial $1 \%$

Berdasarkan hasil perhitungan pengenceran diambil sebanyak $0,1 \mathrm{ml}$ asam asetat glasial $100 \%$ untuk pengenceran asam asetat $1 \%$ dengan menggunakan pipet tetes kemudian dilarutkan menggunakan aquades sebanyak $10 \mathrm{ml}$ dan diaduk homogen. Pengenceran asam asetat $1 \%$ dilakukan di dalam lemari asam.

Penginduksian asam asetat glasial $1 \%$ dengan cara penyuntikan intraperitonial, hewan dipegang punggungnya sehingga kulit abdomennya menjadi tegang. Pada saat penyuntikan posisi kepala mencit lebih rendah dari abdomennya. Cara penyuntikan dengan memiringkan jarum dibagian tepi abdomen dari garis tengah untuk menghindari terkenanya kandung kemih dan jangan pula terlalu tinggi agar tidak mengenai hati. Volume penginduksian pada metode geliat ini sebanyak $0,1 \mathrm{ml}$ dilakukan 30 menit setelah pemberian sediian uji.

\subsubsection{Pengelompokan Hewan Percobaan}

Pada penelitian kali ini hewan percobaan akan dibagi secara acak menjadi 5 kelompok masing-masing terdiri dari 5 ekor mencit putih jantan. Mencit dipuasakan terlebih dahulu selama 16 jam, tiap kelompok diberi perlakuan sebagai berikut :

1. Kelompok pertama adalah sebagai kontrol negatif hanya diberi aquades secara peroral sebanyak $1 \%$ dari BB tiap mencit dan 30 menit kemudian diberikan asam asetat glasial $1 \%$ secara intraperitonial sebanyak $0,1 \mathrm{ml}$.

2. Kelompok kedua adalah sebagai kontrol positif diberi larutan suspensi asam asetilsalisilat dengan dosis $65 \mathrm{mg} / \mathrm{kgBB}$ secara peroral sebanyak $1 \%$ dari BB tiap mencit dan 30 menit kemudian diberikan asam asetat glasial $1 \%$ secara intraperitoneal sebanyak $0,1 \mathrm{ml}$.

3. Kelompok ketiga adalah mencit diberikan perlakuan infusa daun jeruk nipis (Citrus aurantifolia (Christm.) Swing) dengan konsentrasi $5 \%$ secara peroral sebanyak $1 \%$ dari BB tiap mencit dan 30 menit kemudian diberikan asam asetat glasial $1 \%$ secara intraperitoneal sebanyak $0,1 \mathrm{ml}$.

4. Kelompok keempat adalah mencit diberi perlakuan infusa daun jeruk nipis (Citrus aurantifolia (Christm.) Swing)dengan konsentrasi $10 \%$ secara peroral sebanyak $1 \%$ dari $\mathrm{BB}$ tiap mencit dan 30 menit kemudian diberikan asam asetat glasial $1 \%$ secara intraperitoneal sebanyak 0,1 $\mathrm{ml}$.

5. Kelompok kelima mencit diberi perlakuan infusa daun jeruk nipis (Citrus aurantifolia (Christm.) Swing)dengan konsentrasi $20 \%$ secara peroral sebanyak $1 \%$ dari BB tiap mencit dan 30 menit kemudian diberikan asam asetat glasial $1 \%$ secara intraperitoneal sebanyak 0,1 $\mathrm{ml}$.

\subsection{Analisis Data}

Dari data yang dapat dilakukan uji statistik berupa Analysis of Variance (ANOVA) dua arah dilanjutkan dengan uji Tukey dengan tingkat kepercayaan 95\% menggunakan Software SPSS.

\section{HASIL}

Setelah dilakukan uji efek analgetik infusa daun sukun terhadap mencit putih jantan yang diinduksi asam asetat $1 \%$ didapatkan hasil yang tercantum pada Tabel 1 dan hasil persentase proteksi tercantum pada Tabel 2.

\section{PEMBAHASAN}

Pada penelitian ini dilakukan pengujian efek analgetik infusa daun jeruk nipis (Citrus aurantifolia (Christm.) Swing) terhadap mencit putih (Mus musculus L) jantan dengan motede geliat (writhing test). Pengujian ini dilakukan untuk melihat manfaat analgetik yang ada pada infusa daun jeruk nipis. Secara tradisional masyarakat menggunakan daun jeruk nipis untuk pengobatan hipertensi, batuk, lendir tenggorokan, demam, panas pada malaria, jerawat, dan ketombe (Hariana, 2008).

Daun yang digunakan adalah daun jeruk nipis yang masih segar. Sampel tumbuhan yang digunakan diambil dari Desa Salo, Kota Bangkinang, Kabupaten Kampar Provinsi Riau.Selanjutnya dilakukan skrining fitokimia dengan tujuan untuk mengetahui kandungan senyawa kimia yang terdapat dalam sampel daun jeruk nipis. Berdasarkan hasil skrining fitokimia yang dilakukan menunjukkan bahwa daun jeruk nipis mengandung senyawa metabolit sekunder alkaloid, terpenoid dan flavonoid. Sedangkan dari hasil skrining fitokimia infusa daun jeruk nipis yang dilakukan menunjukan bahwa infusa daun jeruk nipis mengandung metabolit sekunder flavonoid dan terpenoid. Diketahui bahwa flavonoid yang terdapat dalam daun jeruk nipis merupakan senyawa yang memiliki efek analgetik sehingga berpotensi menghilangkan rasa nyeri.

Pada penelitian ini menggunakan penentuan aktivitas analgetik dengan metode geliat yang 
dilakukan berdasarkan pengamatan jumlah geliatan yang terjadi pada hewan percobaan. Pemberian asam asetat glasial pada hewan percobaan bertujuan untuk merangsang nyeri yang berasal dari reaksi inflamasi akut lokal yaitu pelepasan asam arakidonat dari jaringan fosfolipid melalui jalur siklooksigenase dan menghasilkan prostaglandin, terutama prostaglandin E2 (PGE2) dan prostaglandin F2a (PGF2a) di dalam cairan peritoneal pada hewan tersebut sehingga akan menyebabkan terjadinya geliatan yang merupakan pertanda bahwa hewan tersebut mengalami nyeri. Sedangkan penilaian perlakuan metode geliat yang dilakukan berdasarkan kemampuannya dalam menekan atau menghilangkan rasa nyeri yang diinduksi secara kimia pada hewan percobaan mencit. Rasa nyeri ini pada mencit diperlihatkan dalam bentuk berupa respon gerakan geliat yaitu kedua pasang kaki ke depan dan ke belakang serta perut menekan lantai, yang muncul dalam waktu maksimal lima menit setelah diinduksi larutan asam asetat glacial 1\% (Marlyn, 2012).

Pada uji analgetik penginduksinya yaitu asam asetat glasial 1\%, karena mempunyai nilai bobot molekul yang sama dengan asam asetat. Asam asetat glasial mempunyai BM 60,05 ddengan rumus molekul $\mathrm{C} 2 \mathrm{H} 4 \mathrm{O} 2$ mempunyai paruh waktu 2-3 jam (Anonim, 2014 ; Martindel, 2002). Pemberian larutan induksi asam asetat glasial diberikan secara intraperitonial untuk melihat geliatannya, sedangkan sediaan infusa daun jeruk nipis (Citrus aurantifolia (Christm.) Swing) diberikan secara oral terhadap perlakuan kerena agar dapat langsung sampai di saluran cerna dan segera diabsorbsi oleh tubuh. Jalur pemakain obat secara oral merupakann jalur pemakain obat yang umum digunakan, mudah diberikan dan aman.

Asam asetil salisilat merupakan golongan salisilat yang mempunyai aktifitas sebagai analgetik-antipiretik dan antiinflamasi yang sangat luas digunakan dan mempunyai efek yang sangat kuat dibandingkan analgetik perifer lainnya, digolongkan dalam obat bebas serta menjadi stadar untuk pembanding dan evaluasi obat. Mekanisme kerja dengan menghambat enzim siklooksigenase sehingga prostaglandin (PGE2, PGF2, dan PGL2), tromboksan A2 terhambat. Penghambatan produksi prostaglandin yang merupakan salah satu senyawa yang dapat meningkatkan kesensitifan nosireseptor, dapat menurunkan jumlah implus nyeri yang diterima oleh sistem saraf pusat (Ganiswarna, 1995 ; Wilmana, 2005).

Tabel.1 Data Rata-rata Jumlah Geliatan Hewan Percobaan Selang Waktu 5 Menit Selama 60 Menit Pengamatan

\begin{tabular}{|l|c|c|c|c|c|c|c|c|c|c|c|c|}
\hline & \multicolumn{10}{|c|}{ Rata-rata Jumlah Geliatan dalam Waktu (Menit) } \\
\hline & 5 & 10 & 15 & 20 & 25 & 30 & 35 & 40 & 45 & 50 & 55 & 60 \\
\hline kontol negative & 2.4 & 10.8 & 8.2 & 12.4 & 9.4 & 6.6 & 5.8 & 4.4 & 3.8 & 2.4 & 3.8 & 3 \\
\hline kontrol positif & 4.2 & 2.8 & 2 & 1.8 & 1.2 & 0.8 & 0.4 & 0.4 & 0.4 & 0 & 0 & 0 \\
\hline konsentrasi 5\% & 9.2 & 10.2 & 7.4 & 7.4 & 6.2 & 5.6 & 5.2 & 4.4 & 4.2 & 3.4 & 3 & 1.4 \\
\hline konsentrasi 10\% & 6.8 & 7.4 & 6 & 4.8 & 4 & 3.4 & 1.6 & 0.6 & 0.4 & 1 & 0.4 & 0.2 \\
\hline konsentrasi $20 \%$ & 6.6 & 5.2 & 4 & 3 & 1.4 & 1.8 & 0.6 & 0.4 & 0.4 & 0.2 & 0.2 & 0 \\
\hline
\end{tabular}


Jurnal Penelitian Farmasi Indonesia 9(1), Juni 2020

ISSN : 2302-187X $\quad e$-ISSN 2656-3614

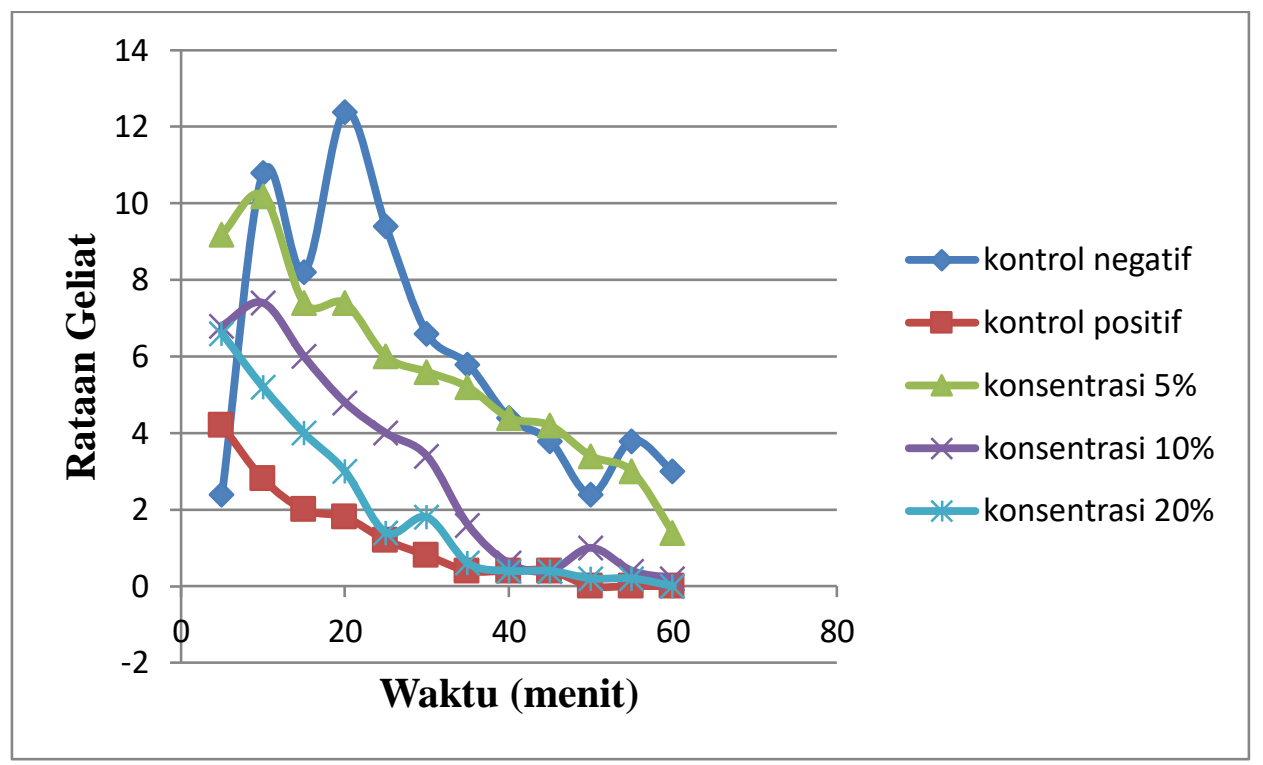

Gambar.1 Grafik Rata-Rata Geliatan Yang Terjadi Selang Waktu 5 Menit Selama 60 Menit Pengamatan

Pensuspensi yang digunakan adalah $\mathrm{Na}$ CMC dengan konsentrasi $1 \%$ dimana pada konsentrasi ini senyawa dapat larut dengan baik dan juga merupakan konsentrasi yang biasa digunakan untuk sediaan oral. Pembuatan sediaan uji untuk kelompok kontrol positif yang menggunakan asetosal disuspensikan dengan $\mathrm{Na}$
CMC karena asetosal agak sukar larut dalam air (Anonim, 2014). Penggunaan Na CMC ini adalah kerena dapat menghasilkan suspensi yang stabil, kejernihannya tinggi dan bersifat inert sehingga tidak mempengaruhi zat berkhasiat. Na CMC dipilih sebagai pensuspensi kerena mempunyai toksisitas yang rendah dan terdispersi di dalam air dibandingkan dengan pensuspensi lain.

Tabel 2. Data Hasil Rata-rata Persen Proteksi Infusa Daun Jeruk Nipis (Citrus aurantifolia (Christm.) Swing) Tiap-Tiap Perlakuan

\begin{tabular}{|l|c|c|c|c|c|c|c|c|c|c|c|c|}
\hline & \multicolumn{10}{|c|}{ Menit ke } \\
\hline & 5 & 10 & 15 & 20 & 25 & 30 & 35 & 40 & 45 & 50 & 55 & 60 \\
\hline kontol negatif & 0 & 0 & 0 & 0 & 0 & 0 & 0 & 0 & 0 & 0 & 0 & 0 \\
\hline kontrol positif & -75 & 74.1 & 75.6 & 85.5 & 87 & 88 & 93.1 & 90.9 & 89.5 & 100 & 100 & 100 \\
\hline konsentrasi 5\% & -283.3 & 5.6 & 9.8 & 40.3 & 36.2 & 15.2 & 10.3 & 00.0 & -10.5 & -41.7 & 21.1 & 53.3 \\
\hline konsentrasi 10\% & -183.3 & 31.5 & 26.8 & 61.3 & 57.4 & 48.5 & 99.7 & 86.4 & 89.5 & 58.3 & 99.9 & 93.3 \\
\hline konsentrasi 20\% & -175.0 & 51.9 & 51.2 & 75.8 & 85.1 & 72.7 & 89.7 & 90.9 & 89.5 & 91.7 & 94.7 & 100 \\
\hline
\end{tabular}


Jurnal Penelitian Farmasi Indonesia 9(1), Juni 2020

ISSN : 2302-187X $\quad e$-ISSN 2656-3614

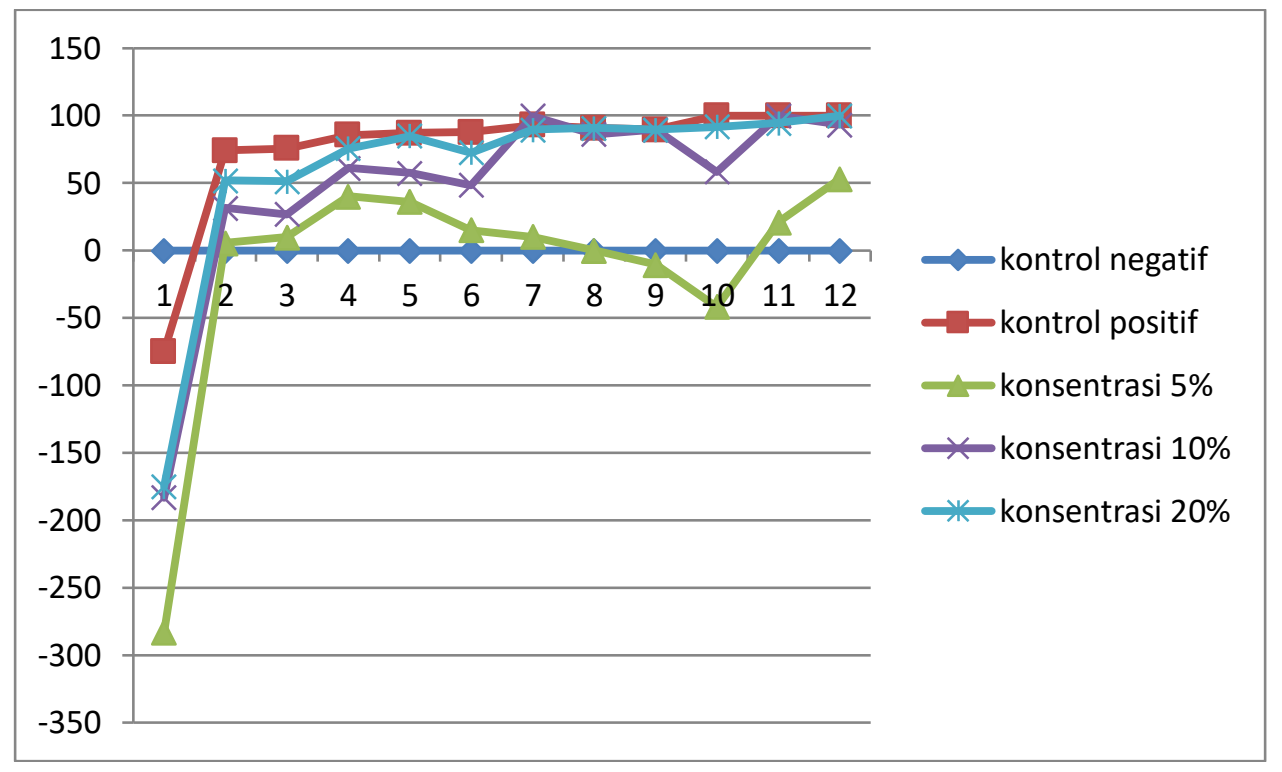

Gambar 2. Grafik Persen Proteksi Infusa Daun Jeruk Nipis (Citrus aurantifolia (Christm.) Swing) TiapTiap Perlakuan

Pada penelitian ini menggunakan hewan uji berupa mencit putih (Mus musculus L) jantan. Alasan penggunaan hewan uji berupa mencit karena mudah diperoleh, mudah dalam perlakuan, mudah dalam pemeliharaan dan kerena sifat fisiologisnya yang hampir mirip dengan manusia serta karena induksi bahan kimia secara intraperitonial pada mencit akan menimbulkan iritasi pada perut dan mengakibatkan efek geliat (Parmar \& Prakash, 2006).

Pemilihan jenis kelamin jantan yaitu didasarkan pertimbangan bahwa kondisi hormonal mencit jantan yang lebih stabil dibandingkan dengan mencit betina, karena mencit betina mengalami perubahan kondisi hormonal pada masa-masa tertentu seperti pada masa siklus estrus, masa kehamilan dan menyusui yang dapat mempengaruhi kondisi fisiologis hewan uji.Sehinggga dikhawatirkan dapat berpengaruh terhadap hasil pengujian. Selain itu tingkat stres pada mencit betina juga lebih tinggi bila dibandingkan dengan mencit jantan yang mungkin dapat mengganggu dalam proses penelitian (Vogel, 2002)

Sebelum pengujian mencit diaklimatisasi terlebih dahulu selama 7 hari dengan tujuan unuk penyesuaian terhadap lingkungan.Hewan uji dinyatakan sehat apabila selama pengamatan tidak menunjukkan deviasi berat badan $(>10 \%)$ dan secara visual tidak menunjukkan gejala yang tidak sehat (Anonim, 2014). Mempunyai berat badan yang kurang lebih sama dibagi dalam lima kelompok. Dengan cara ini diharapkan pembagiannya akan merata dan data yang dihasilkan akan mendekati sama (lebih homogen). Sehari sebelum pengujian masing-masing mencit dipuasakan terlebih dahulu selama 16 jam tetapi tetap diberikan air minum. Hal ini dilakukan untuk menghindari kemugkinan adanya faktor yang dapat mempengaruhi hasil pengujian analgetik yang timbul akibat dari makanan yang diberikan pada mencit (Vogel, 2002).

Berdasarkan hasil penelitian yang dilakukan diperoleh hasil persentase proteksi maksimal ratarata untuk tiap kelompok perlakuan yaitu : kelompok kontrol positif yang diberi asam asetil salisilat sebesar $100 \%$ pada menit ke-50, infusa konsentrasi 5\% sebesar 53,3\% pada menit ke-60, infusa konsentrasi $10 \%$ sebesar $99,9 \%$ pada menit ke-55, dan infusa konsentrasi $20 \%$ sebesar $100 \%$ pada menit ke-60 .

Tabel 3. Hasil Uji Subset Homogenetik Efek Analgetik Infusa Daun Jeruk Nipis (Citrus aurantifolia (Christm.) Swing) Terhadap Perlakuan 
Jurnal Penelitian Farmasi Indonesia 9(1), Juni 2020

ISSN : 2302-187X $\quad e$-ISSN 2656-3614

\begin{tabular}{|c|c|c|c|c|c|}
\hline \multirow{2}{*}{ Perlakuan } & \multirow{2}{*}{ N } & \multicolumn{3}{|c|}{ Subset } & $\mathbf{4}$ \\
\cline { 2 - 6 } & & $\mathbf{1}$ & $\mathbf{2}$ & & \\
\hline Konsentrasi 5\% & 60 & $-11,988$ & & & \\
\hline Kontrol Negatif & 60 &, 000 & 47,438 & & \\
\hline Konsentrasi 10\% & 60 & & & 60,678 & \\
\hline Konsentrasi 20\% & 60 & & & & 75,718 \\
\hline Kontrol Positif & 60 &, 070 & 1,000 & 1,000 & 1,000 \\
\hline Sig. & & & & & \\
\hline
\end{tabular}

Infusa konsentrasi $10 \%$ dan $20 \%$ memberikan persentase proteksi yang berbeda signifikan dengan kelompok kontrol positif, hal ini disebabkan semakin besar konsentrasi infusa dari daun jeruk nipis yang digunakan maka semakin besar jumlah zat aktif yang terkandung didalamnya, sehingga kemampuan persentase proteksi terhadap nyeri yang dihasilkan tiap-tiap perlakuan semakin besar. Semakin kecil jumlah geliatan semakin besar pula persen proteksi yang dihasilkan.Pada hewan atau pada manusia respon terhadap dosis suatu obat yang rendah biasanya meningkat dan berbanding langsung dengan meningkatnya dosis, jadi ada hubungan antara dosis dan efek yaitu berbanding lurus (Harmita dan Radji, 2008).
Dari hasil uji statistika menggunakan analisa varian dua arah yang dilanjutkan dengan Uji Lanjut Tukey terhadap data yang diperoleh menunjukkan bahwa persentase proteksi konsentrasi $5 \%$ tidak berbeda signifikan dengan kontrol negatif ( $\mathrm{p}>0,05)$, akan tetapi konsentrasi $5 \%$ berbeda signifikan dengan konsentrasi $10 \%$ dan konsentrasi $20 \%(\mathrm{p}<0,05)$, hal yang sama terjadi pada konsentrasi $10 \%$ yang berbeda signifikan dengan konsentrasi $5 \%$ dan konsentrasi $20 \%$ ( $\mathrm{p}<0,05)$. Serta konsentrasi $20 \%$ berbeda signifikan dengan konsentrasi $5 \%$ dan konsentrasi $20 \%$ ( $\mathrm{p}<0,05)$, sedangkan pada konsentrasi 5\% tidak memiliki efek analgetik, dan pada konsentrasi $10 \%$ dan $20 \%$ memiliki efek analgetik karena memiliki daya analgetik yang berbeda dengan kontrol negatif.

Tabel 4. Hasil Uji Statistik Subset Homogenitas Efek Analgetik Infusa Daun Jeruk Nipis (Citrus aurantifolia (Christm) Swing)

\begin{tabular}{|c|c|c|c|c|c|}
\hline \multirow{2}{*}{ Waktu } & \multirow{2}{*}{$\mathbf{N}$} & \multicolumn{3}{|c|}{ Subset } & $\mathbf{3}$ \\
\cline { 3 - 6 } & & $\mathbf{1}$ & $\mathbf{2}$ & \\
\hline Menit ke-5 & 25 & $-143,356$ & 32,584 & & \\
\hline Menit ke-10 & 25 & & 34,664 & & \\
\hline Menit ke-15 & 25 & & 41,664 & 41,664 & \\
\hline Menit ke-50 & 25 & & 44,832 & 44,832 & \\
\hline Menit ke-30 & 25 & & 51,584 & 51,584 & 51,584 \\
\hline Menit ke-45 & 25 & & 52,576 & 52,576 & 52,576 \\
\hline Menit ke-20 & 25 & & 53,196 & 53,196 & 53,196 \\
\hline Menit ke-25 & 25 & & 53,636 & 53,636 & 53,636 \\
\hline Menit ke-40 & 25 & & & 58,572 & 58,572 \\
\hline Menit ke-35 & 25 & & & 63,144 & 63,144 \\
\hline Menit ke-55 & 25 & & & & \\
\hline
\end{tabular}


Jurnal Penelitian Farmasi Indonesia 9(1), Juni 2020

ISSN : 2302-187X $\quad e$-ISSN 2656-3614

\begin{tabular}{|c|c|c|c|c|c|}
\hline Menit ke-60 & 25 & & & 69,336 \\
\hline Sig. & & 1,000 &, 124 &, 106 &, 342 \\
\hline
\end{tabular}

Bila dilihat terhadap variabel waktu secara statistika terlihat pada menit ke 5 berbeda signifikan dengan menit ke $10,15,20,25,30,35,0,45,50,55$ dan 60 ( $\mathrm{p}<0,05)$, pada menit ke $10,15,20,25,30,40,50$ tidak berbeda signifikan $(\mathrm{p}>0,05)$ namun berbeda signifikan dengan menit ke 5, 35, 55 dan 60 ( $\mathrm{p}<0,05$ ), pada menit 20, 25, 30, 35, 40, 45, 50 dan 55 tidak berbeda signifikan ( $\mathrm{p}>0.05)$ namun pada menit 5, 10, 15 dan 60 berbeda signifikan $(\mathrm{p}<0.05)$, pada menit ke 20, 25, 35, 40, 45, 55 dan 60 tidak berbeda signifikan $(\mathrm{p}>0,05)$ namun pada menit ke 5, 10, 15, 30 dan 50 berbeda signifikan $(\mathrm{p}<0,05)$. Hal ini menunjukan adanya pengaruh waktu terhadap efek analgetik dari zat uji.

\section{KESIMPULAN}

Berdasarkan hasil penelitian yang telah dilakukan dapat disimpulkan bahwa infusa daun jeruk nipis(Citrus aurantifolia (Christm.) Swing) yang di ujikan terhadap mencit putih (Mus musculus L) jantan dengan metode geliat (Writhing test) dapat memberikan efek analgetik. Pemberian infusa daun jeruk nipis pada konsentrasi $10 \%$ dan $20 \%$ dapat mengurangi rasa nyeri pada mencit yang diinduksi dengan asam asetat glasial $1 \%$ tetapi tidak sekuat kontrol positif.

\section{DAFTAR PUSTAKA}

Anonim. 2014. Farmakope Indonesia. Edisi V. Dapartemen Kesehatan RI. Jakarta.

Ganiswarna, S. 1995. Farmakologi dan Terapi, Edisi IV.Bagian Farmakologi Fakultas Kedokteran Universitas Indonesia. Jakarta.
Clearinsyah, E.P.2016.Efek Analgesik Ekstrak Daun Jeruk Nipis (Citrus aurantifolia) pada Mencit (Mus musculus) Yang Diinduksikan Dengan Asam Asetat. Skripsi. UNTAD. Palu

Gunawan, S.G. 2008.Farmakologi dan Terapi.Edisi 5. Balai Penerbit FKUI. Jakarta.

Hariana, A. 2008.Tumbuhan Obat dan Khasiatnya Seri 1. Penerbit Penebar Swadaya. Jakarta.

Harmita dan Radji, M. 2008.Buku Ajar Analisis Hayati.Edisi III. Penerbit Buku Kedokteran EGC. Jakarta.

Marlyn, R. 2012. Uji Efek Analgetik Ekstrak Etanol 70\% Bunga Mawar (Rosa chinensis jacq) Pada Mencit yang Diinduksi Asam Asetat.Skripsi. Universitas Indonesia. Jakarta.

Parmar. N. S. dan Prakash. S. 2006. Screening Methods in Pharmachology.Alpa Science International. Oxford.

Sherwood L. 2012. Anatomi dan fisiologi manusia dari sel ke sistem.EGC. Jakarta.

Vogel, H. 2002. Drug Discovery and Evaluation Pharmacological Assay, (second edition). New York: Springer Verlag Berlin Heidelberg.

Wahyuni, D. K. Ekasari, W. Witono, J. R. Purnobasuki, H. 2016. Toga Indonesia. Airlangga University Press. Surabaya 